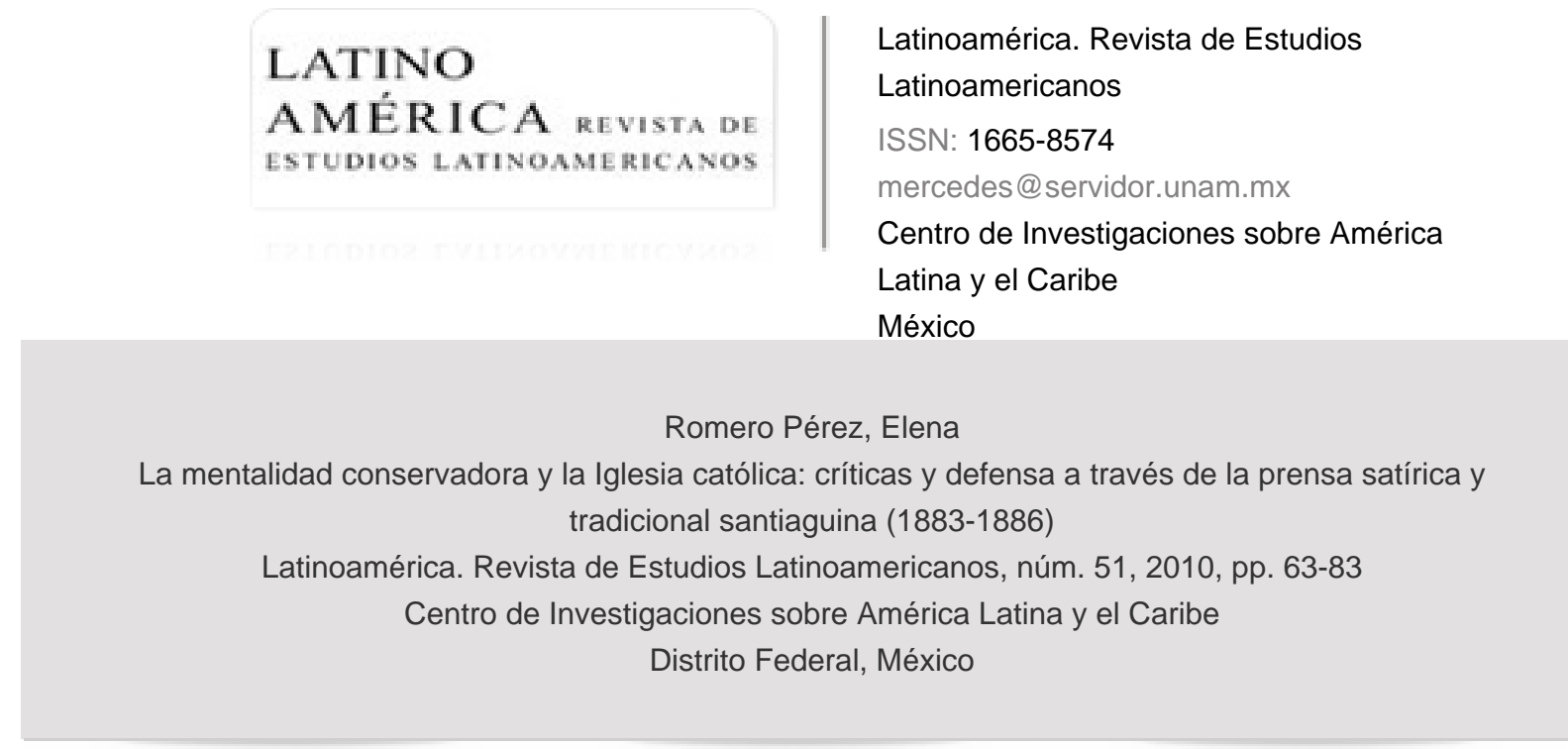

Disponible en: http://www.redalyc.org/articulo.oa?id=64015153004

Cómo citar el artículo

- Número completo

- Más información del artículo

- Página de la revista en redalyc.org

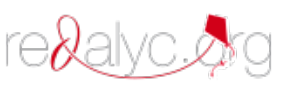

Sistema de Información Científica

Red de Revistas Científicas de América Latina, el Caribe, España y Portugal Proyecto académico sin fines de lucro, desarrollado bajo la iniciativa de acceso abierto 


\section{La mentalidad conservadora y la Iglesia católica: críticas y defensa a través de la prensa satírica y tradicional santiaguina (1883-1886)}

Elena Romero Pérez*

Resumen: Si bien los problemas entre la Iglesia y el Estado se produjeron en una menor escala en Chile que en otros países como México, resulta un caso emblemático el de las consecuencias de la sucesión arzobispal (1878-1886), durante la cual se mostró a través de la prensa capitalina la mentalidad conservadora que defendía prerrogativas de la Iglesia sobre el Estado, así como su influencia sobre la sociedad; versus las críticas que esta posición suscitaba particularmente en la prensa satííca. Se observan así dos posiciones contrapuestas que usaron diversas estrategias para difundir y consolidar sus ideales en la sociedad santiaguina y chilena.

Palabras clave: Iglesia, Estado, Prensa satírica, Conservadurismo, Liberalismo.

ABSTRAC: Although the problems between the Church and the State were smaller in Chile than in other countries such as Mexico, it is an emblematic case of the consequences of the archbishop succession (1878-1886), during that time it was shown on the capitol's press the conservative mentality that defended the church's prerogatives over the State, as well as their influence over the society, versus the criticism that this position originated particularly on the satirical press. Two opposite positions can be observed, that used different strategies for spreading and consolidating their ideals on both the Chilean and Santiago societies.

Key wORDS: Church, State, Satirical press, Conservatism, Liberalism.

Facultad de Educación, Universidad Mayor, Corporación Chilena de Estudios Históricos, Santiago de Chile (elena.romero@mayor.cl). 
INTRODUCCIÓN

L

a oposición entre liberales y conservadores dio pie a una serie de conflictos en el siglo xIx, proviniendo dicho conflicto de elementos ideológicos y prácticos. Esta contraposición se refleja en las definiciones de cada tendencia, caracterizándose los conservadores por sostener: "[...] una posición frente al gobierno, proponiendo el debilitamiento de la autoridad presidencial y de cualquier exceso de uso del poder". ${ }^{1}$ Contrariamente, el Liberalismo era definido como: "[...] la creencia en un conjunto de métodos y prácticas que tienen como objetivo común lograr una libertad mayor para los individuos [...]", ${ }^{2}$ lo que implicaba rechazar cualquier poder con características autoritarias, por ejemplo el que ostentaba la Iglesia católica. Se opone entonces una concepción basada en principios morales tradicionales y un respeto irrestricto a la autoridad, en el caso de los conservadores; versus una defensa de las libertades a ultranza, en conjunto con una crítica a todo aquello que se opone al desarrollo de éstas.

Un momento de especial efervescencia de esta contraposición se produjo en las décadas de 1880 y 1890, en las que acontecen en Chile la sucesión arzobispal (1878-1886), ${ }^{3}$ las reformas teológicas, ${ }^{4}$ entre otros procesos que afectaron la primacía de la Iglesia en la sociedad. Esto implicó que: "Durante las décadas de 1880 y 1890 [...] el clero descubrió que los enemigos de la nación católica triunfante en el Pacífico o en el Salitre estaban en el mismísimo interior del país. El espíritu

\footnotetext{
${ }^{1}$ Jordi Fuentes y Lía Cortés, Diccionario político de Chile (1810-1966), Santiago de Chile, Orbe, 1967, p. 109.

${ }^{2}$ David Sills, Enciclopedia Internacional de las Ciencias Sociales, Madrid, Aguilar, 1974, vol. III, 787 pp., p. 75.

${ }^{3}$ Este conflicto entre la Iglesia y el Estado se produjo tras la muerte del arzobispo de Santiago Rafael Valentín Valdivieso en 1878. Ante ello, el gobierno de Aníbal Pinto propuso al sacerdote liberal Francisco de Paula Taforó, quien fue rechazado por el Vaticano, lo que dio origen a la disputa sobre las prerrogativas del Estado sobre la Iglesia; llegándose incluso a la ruptura de relaciones diplomáticas en 1883. El problema se solucionó en 1886, con el nombramiento de Mariano Casanova.

${ }^{4}$ Según Salazar y Pinto, dichas reformas llevadas a cabo entre las décadas de 1870 y 1890 buscaban acabar con la unión Iglesia-Estado, de forma que la sociedad pudiese liberarse de su influjo, que a juicio de los liberales era dañino para la sociedad. Información extraída de: Gabriel Salazar, Julio Pinto, Historia contemporánea de Chile: niñez y juventud, Santiago, Lom, 2002, vol. V, p. 136.
} 
y el rostro del clero pasó a demacrarse por culpa de los molestos liberales que intentaban descatolizar a Chile". ${ }^{5}$ A ello ayudaban los diarios que circulaban en el país, como bien señaló el político contemporáneo, Justo Arteaga Alemparte: "La nueva prensa, emancipada de su 'culpable culpabilidad' (Kant) y también del 'aura' estatal, fabulando ad líbitum su propia autonomía, buscará contribuir a la constitución y ampliación de una esfera crítica, raciocinante [sic] e independiente de la autoridad política [... ]".

De allí que la contraposición en la prensa escrita de Santiago entre liberales y conservadores se haya manifestado a diario a través de editoriales, estableciendo disputas que muchas veces eran olvidadas sólo con la aparición de un nuevo tema por el cual discutir. Pero, además, hubo un tipo de diario que molestó a todos los sectores políticos: la prensa satírica, cuya misión principal no era informar sino criticar a la sociedad, a los políticos y a todo aquel que lo mereciese, sin importar si llevaba uniforme o era civil. Un claro ejemplo en Chile fueron los escritos de Juan Rafael Allende, editor de diarios como El Nuevo Ferrocarril, El Padre Padilla y El Padre Cobos. En ellos, fue capaz de criticar la actualidad por medio de escritos e imágenes difundidos en sus páginas centrales con el título "Mis Grabados", acompañados de una irónica poesía que los complementaba.

Su prosa directa y sus dibujos provocadores produjeron amplias reacciones, ya que:

"La élite no pudo soportar el caudal de su obra". Sólo lo percibió como un enemigo mortal. Especialmente el alto clero, abatido por sus ofensas al prestigio de la élite [...]. Mientras la aristocracia con sotana se defendió de espaldas frente a estas cascadas de inmoralidad, Juan Rafael Allende atacó de frente precisamente la gazmoñería estrecha de una élite moralista —no sólo católica - que acabó encerrándose autísticamente consigo misma? ${ }^{7}$

${ }^{5}$ Citado en Maximiliano Salinas Campos, YYa no bablan de Jesucristo! Las sátiras al alto clero y las mentalidades religiosas en Chile a fines del siglo XIX, Santiago, LOM, 1999, 52 pp., pp. 13 y 14.

6 Justo Arteaga Alemparte, "La Semana, 3 de marzo, 1860, núm. 35", en Carlos Ossandón, El crepúsculo de los sabios y la irrupción de los publicistas, Santiago, Lom, 1998, 127 pp., p. 99.

${ }^{7}$ Maximiliano Salinas Campos, "Erotismo, humor y transgresión en la obra satírica de Juan Rafael Allende", en Mapocho. Revista de Humanidades y Ciencias Sociales, núm. 57, Santiago, 2005/1, pp. 149-248, pp. 245 y 246. 
La principal amenaza era que estos mensajes llegaban a la población analfabeta, ya que como reza el dicho popular: "una imagen vale más que mil palabras". De hecho, su alcance se relaciona con: "La caricatura, como recurso visual y documento histórico, refuerza y brinda al público no sólo estos conceptos - críticostraducidos en signos, sino también elementos de identidad de las personalidades políticas más destacadas [...]. Se ridiculizaba a algunos y se atribuían virtudes a otros". ${ }^{8}$ De allí que el valor de la caricatura reside en la plena conexión con el humor, puesto que: "[...] ha sido creada como algo que vive y palpita independiente y autónomo de influencias que no estén dentro de la línea como elemento plástico, y de la filosofía del humor como motivación", ${ }^{2}$ logrando entonces combinar una crítica a la sociedad, con el arte del hacer reír. Con base en todo lo anterior es que planteamos como hipótesis que los diarios El Padre Padilla y El Padre Cobos fueron considerados peligrosos por el clero y el sector conservador, debido principalmente a sus imágenes más que a sus escritos, ya que lo mordaz y explícito de sus dibujos expresaba fuertes críticas al pensamiento conservador, las que podían difundirse ampliamente en los sectores populares, teniendo en cuenta que en ese tiempo los índices de alfabetización eran muy bajos. ${ }^{10}$ Presentamos como objetivos generales reconocer las representaciones de crítica a la mentalidad y actitud conservadora, en especial a la Iglesia católica en la prensa liberal a través de los diarios satíricos El Padre Padilla y El Padre Cobos; y analizar la reacción del sector criticado, por medio del Edicto sobre las malas lecturas ${ }^{11}$ y algunos editoriales del periódico El Chileno. Para ello se plantea la utilización de la prensa como fuente primaria, en especial los diarios

\footnotetext{
${ }^{8}$ María Luiza Tucci Carneiro, "La Guerra Civil Española a través de las revistas ilustradas brasileñas: imágenes y simbolismos", en Estudios Interdisciplinarios de América y el Caribe, 1991/2, vol. 2, núm. 2. En http://www.tau.ac.il/eial/II_2/carneiro.htm.

9 Antonio R. Romera, "La caricatura moderna", en Atenea. Revista Mensual de Ciencias, Letras y Artes, año XVIII, t. LXIV, núm. 192, Santiago, junio de 1941, p. 308.

10 "En 1854 el índice de alfabetización era de 13.5\% de la población y ascendió a 28.9\% en 1885", en Sol Serrano, Universidad y nación: Chile en el siglo XIX, Santiago, Universitaria, 1994, 276 pp., p. 15.

${ }^{11}$ Edicto expedido por el obispo capitular Joaquín Larraín Gandarillas, en septiembre de 1886, publicado en el periódico El Estandarte Católico, 13 de octubre, 1886.
} 
ya señalados, además de fuentes secundarias y obras generales relacionadas con los temas a tratar.

La crítica a la mentalidad Conservadora a través de El PadRE Cobos y El PadRE PADILLA

La prensa satírica en Chile se originó tras el comienzo del proceso de independencia, en particular los primeros registros se encuentran hacia 1811 en pasquines callejeros. Ésta aumentó su importancia con el correr del siglo xIx, al destacarse los escritos del ya mencionado Juan Rafael Allende quien, a través de múltiples publicaciones, dejó fluir toda su crítica a la Iglesia católica y a la aristocracia, sus periódicos no estuvieron exentos de cierres y censuras por parte de los gobiernos de turno. Lo anterior se refleja en imágenes y escritos como los siguientes:

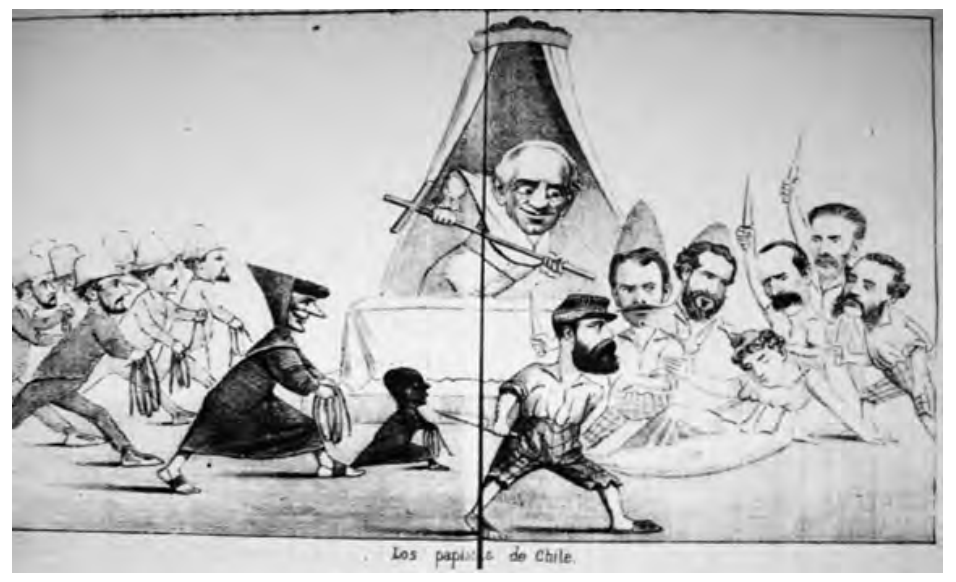

Imagen 1: Caricatura y texto titulado: Los papistas de Chile, en El Padre Cobos, Santiago, martes 30 de enero, 1883, pp. 2 y 3. 
En la imagen se observa a primera vista una contraposición entre dos bandos definidos: el del costado derecho, en el que una serie de prohombres del partido conservador se dispone a atacar con puñales a una mujer que representa la República chilena, puñales que si observamos con detenimiento son empuñados de espalda a ella, lo que implica la idea de: "traición a la patria". Dos hombres - los más cercanos al centro de la imagen- están con grandes sombreros, y por sus características nos recuerdan los usados por los hombres de Iglesia. Hacia el centro se encuentra un hombre: José Francisco Vergara, quien intentó ser candidato a la presidencia de la República contra el electo, y finalmente candidato único, José Manuel Balmaceda en las elecciones de 1886. En el costado izquierdo está el padre Cobos junto con su fiel empleado "el Negro", ${ }^{12}$ ambos se disponen en primera fila a acercarse a defender a la República con sogas en sus manos. Tras ellos, un grupo de hombres que por los tipos de sombreros parecen ser de todas las clases sociales, también se aprestan a ir en auxilio de ella. Finalmente al centro, se encuentra un hombre vestido de blanco, cuya vestimenta nos recuerda a la del Papa, quien con la parte trasera de una gran cruz, se dispone a atacar sigilosamente a la República.

¿Qué crítica subyace en la mentalidad conservadora? Para responder, nos apoyaremos en la poesía que acompaña a las imágenes. Creemos que la idea central de este grabado es mostrar cómo el partido conservador - que no es casual se encuentre a la derecha de la imagen y del Papa - es capaz de traicionar a su propio país si es necesario, para defender totalmente lo que la religión católica indica como correcto de hacer. Esta idea se ve apoyada en el escrito, ${ }^{13}$ cuando se explicita que:

\footnotetext{
${ }^{12}$ El Negro era una figura que acompañó al padre Cobos tras la Guerra del Pacífico, la cual enfrentó a Chile contra Bolivia y Perú entre 1879 y 1883. Con ello, se indicaría que su acompañante era de origen peruano, lo que muestra las tendencias racistas de la época.

${ }^{13}$ Extractos de: Mis Grabados: Los papistas de Chile, en El Padre Cobos, Santiago, martes 30 de enero, 1883, p. 4. Aclaramos aquí que hemos mantenido la escritura original de la época, por lo que no necesariamente ésta coincide con los cánones de la escritura actual.
} 
Estos papistas, so capa

De relijion o de broma,

Son una buena carcoma,

Un jefe tienen: el Papa,

Tienen una patria: Roma.

Ni uno solo hai que vacile

En dar una puñalada

A Chile, si al Papa agrada...

Por fortuna para Chile,

Chile no es Nueva Granada!

De lo dicho clara muestra

Siempre el bando clerical
Dió, llevando a la palestra

Un crucifijo en la diestra,

I en la siniestra un puñal.

No temais a esos chacales,

Que hai solamente un pechoño,

Por cada mil liberales.

iNegro cara de aceituna!

Hoi tu ayuda es oportuna,

Traeme algunos cordeles

Para atar a esos lebreles

Que están ladrando a la luna!

En el texto se presenta una clara oposición entre conservadores y liberales: los primeros se destacan por su irrestricta lealtad al Papa, lo cual los llevó a ser considerados por algunos sectores radicales como traidores, además de ser cobardes al realizar sus acciones de espaldas al conocimiento público. El bando liberal se presenta en la imagen como más cohesionado, y en la lectura como más numeroso que los conservadores, dispuestos a acallar a estos últimos en defensa del país. Finalmente, es evidente que resulta ofensivo el trato de los conservadores como perros, siendo nuestra conclusión que este grabado es una crítica a la lealtad de los tradicionalistas con el Papa, algo visto por los liberales como peligroso para el bienestar y equilibrio del país. 


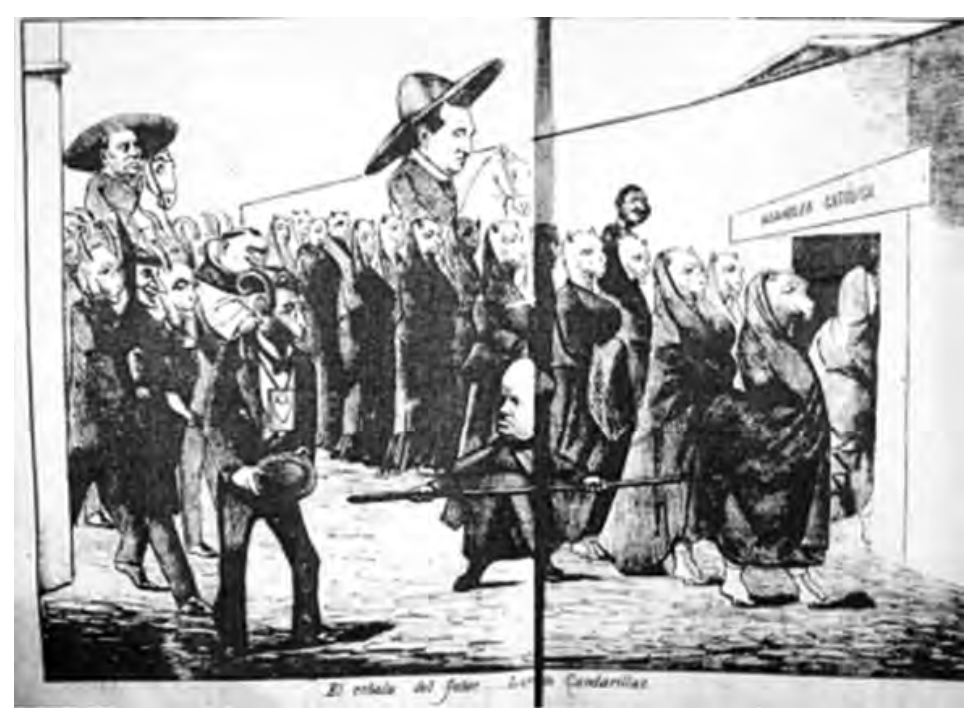

Imagen 2: Mis grabados. El rebaño del señor... Larraín Gandarillas, ${ }^{14}$ en El Padre Padilla, Santiago, 4 de noviembre, 1884, pp. 2 y 3.

En la imagen destacan varios elementos:

- La presencia de figuras femeninas con cara de cordero, ${ }^{15}$ las cuales entran primero y en masa a un lugar señalado como "Asamblea Católica". Ello alude a las mujeres conservadoras y católicas que irían a misa. Tras las mujeres, se encuentran los hombres con caras de cabritos, quienes las secundan en su entrada al templo.

- En dos caballos, al medio de la multitud se encuentran dos hombres vestidos de curas: el de más al fondo es monseñor Joaquín Larraín Gandarillas, vicario capitular del arzobispado de Santiago. En el extremo izquierdo de la imagen apa-

${ }^{14}$ Monseñor Joaquín Larraín Gandarillas fue arzobispo auxiliar de Santiago durante la sucesión arzobispal, fue conocido por su tendencia extremadamente conservadora.

${ }^{15}$ Según Juan Eduardo Cirlot, la figura del cordero implica una actitud de: "pureza, inocencia, mansedumbre (inmerecido sacrificio)". Juan Eduardo Cirlot, Diccionario de símbolos, epílogo de Victoria Cirlot, 10ª ed., Barcelona, Siruela, 2006, p. 150. 
rece el padre Cobos, y cerca de él la imagen de un fraile regordete de satánica mirada y risa. Cerca de ellos, en primer plano y en actitud humilde, está un hombre con cara de cabrito, que va bien vestido y lleva un dibujo del Sagrado Corazón colgado en su pecho. Lo aleja de los fieles un enano ${ }^{16}$ con actitud desafiante, que es mirado de reojo por el primer cura a caballo.

La crítica a la mentalidad conservadora se refleja en el grabado anterior en el aspecto de la mansedumbre: los fieles católicos se dejan llevar cuales sumisos corderos - y cabritos - por el guía de la Iglesia católica en Chile: monseñor Larraín Gandarillas, quien podía influir en su "rebaño" cristiano, que lo obedecería sin chistar, siendo las mujeres quienes serían incluso "sacrificadas" al asistir a misa.

Se encuentra también la idea de la separación de los sexos en el culto, ya que por medio de esto se trataba de evitar el contacto directo entre hombres y mujeres para evitar "distracciones". Además, se observan elementos clasistas en el cabrito que porta la imagen del Sagrado Corazón, quien si bien está bien vestido, se halla en actitud humilde. Es conocido que las clases populares, hasta nuestros días, se aprestan a asistir a misa con las mejores prendas que posean. De ahí que el intento de ingresar a la asamblea se ve frenado por este enano, que con abierta hostilidad le impide acercarse a la entrada mientras hacen ingreso las mujeres; aunque pareciera estarlo echando del lugar, más que incitarlo a que aguarde su turno de entrada. Ello implicaría que esta figura maligna pretendería incluso alejar a un ferviente fiel que, por su condición socioeconómica, no merecería entrar en la asamblea católica, una crítica al clasismo al interior de la Iglesia. El escrito del grabado nos aporta:

${ }^{16}$ Según Cirlot, la figura del enano es tomada por la sabiduría popular como un ser tradicionalmente maligno, al ser considerado, en algunas ocasiones por la pequeñez, como una referencia a los pocos conocimientos, vinculándose entonces con la ignorancia y la inferioridad. Superar a un enano significaría entonces lograr sabiduría. Cirlot, op. cit., pp. 188 y 189. 


\begin{tabular}{|c|c|}
\hline Ya está espedito el corral & Os predican la humildad \\
\hline Para carneros i ovejas & Como uno de los más caros \\
\hline Del rebaño clerical. & Dones de la cristiandad, \\
\hline Aprontad vuestras guedejas! & Para poder ensillaros \\
\hline La trasquila es jeneral! & Con toda facilidad. \\
\hline A vosotras mansas beatas, & Os predican el ayuno, \\
\hline Que ni siquier sois capaces & Que vuestra existencia acorta \\
\hline De quejaros timoratas, & I no os dá provecho alguno, \\
\hline Si os tusan los capataces & Para comerse la torta \\
\hline Desde el hocico a las patas; & Sin convite de importuno. \\
\hline Veréis como don Joaquin, & La cristiandad os predican \\
\hline Ese pastor ejemplar, & I el criminal celibato \\
\hline Os obligará por fin & iellos! Que se identifican \\
\hline En una ajencia a empeñar & con el criminal chibato \\
\hline El moño y el potolín. & i vuestro honor sacrifican. \\
\hline ¿Para qué? Para mañana & Corred pues, a la asamblea, \\
\hline Gastar en las elecciones & Ovejitas y carneros, \\
\hline Hasta cuando le dé la gana & I más tarde no os vea, \\
\hline Los escudos y doblones & Haciendo a todos pucheros, \\
\hline Que saque de vuestra lana (...) & Con cólico o con diarrea! \\
\hline
\end{tabular}

En los párrafos anteriores, se especifica aún más lo relacionado con el aprovechamiento de la obediencia de sus fieles por parte de la Iglesia, lo que se ve remarcado en tres ámbitos particulares: el uso del dinero que se entrega a la Iglesia, que sería tomado por Larraín Gandarillas para aumentar su poder y lograr influir en el ámbito político. ${ }^{17}$ De hecho, el vicario capitular fue un blanco constante de

${ }^{17}$ Esta crítica no era extraña entre los contemporáneos. De hecho, el político e historiador Miguel Luis Amunátegui indicaba que: "[...] la autoridad eclesiástica y el clero, por atender a ventajas puramente temporales, han apadrinado en diversas ocasiones con el mayor empeño y decisión 
los ataques de Allende, quien despectivamente también lo llamaba "el tuerto". Un segundo elemento lo constituye el abuso de confianza que ejercería el clero con las mujeres, lo que lleva a que los maridos de las feligresas sean unos "cachudos" o "cornudos" al ser engañados por sus esposas con los sacerdotes. Esto también será tema de otros grabados, en los que se insinúa que el cura párroco no era sólo el padre espiritual de sus feligreses, sino también el padre biológico de parte de éstos. Finalmente, tenemos el dicho popular: "Es como el padre Gatica: predica pero no practica". Justamente a esto apuntan tres párrafos del texto: al ayuno, la abstinencia y la humildad, elementos que encuentran su contraste con la imagen del fraile regordete, de los hombres con cuernos como señal de haber sido engañados por sus esposas y la ambición atribuida al pastor de la Iglesia chilena.

Vemos entonces cómo se critica la contradicción existente entre la mentalidad católica-conservadora y las prácticas efectivas, mostrándonos a estos sectores como hipócritas y aprovechadores.

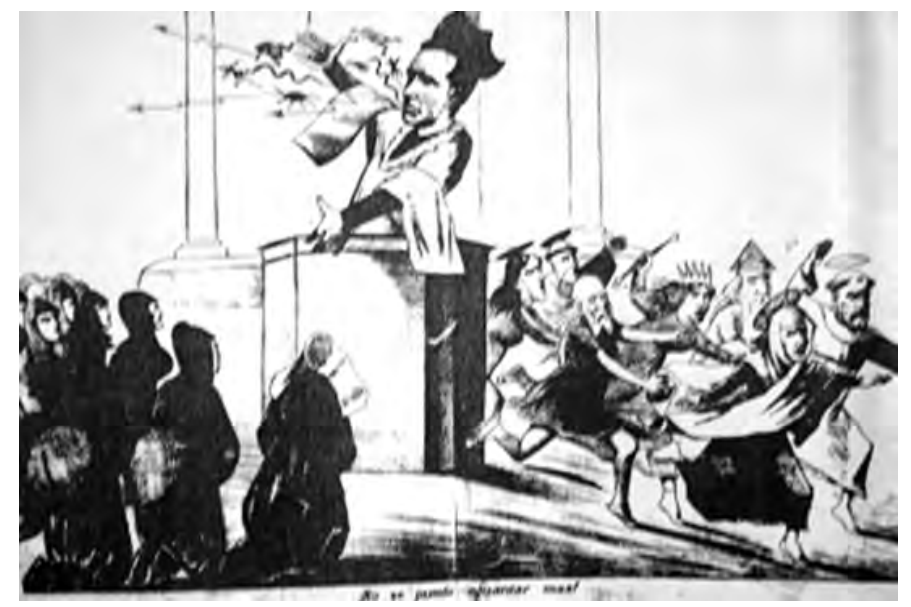

Imagen 3: iNo se puede aguantar más!, en El Padre Padilla, Santiago, 28 de noviembre, 1884, pp. 2 y 3.

causas muy mundanas que la opinión general ilustrada por el curso de los acontecimientos, ha condenado como dañosas o injustas [...]. La conclusión que yo deducía de estos antecedentes era que los representantes del principio religioso debían abstenerse cuidadosamente de tomar 
Esta imagen resulta ser clave en cuanto se aprecia plenamente el uso del humor como recurso crítico. Mientras en el sector inferior izquierdo se ve a las feligresas escuchar atentamente a un sacerdote - que tiene cierto parecido con Francisco de Paula Taforó $-{ }^{18}$ ubicado al centro de la imagen, quien lanza rayos, sapos y culebras mientras habla; a la derecha de la imagen se observa una serie de santos - entre ellos San Pedro y San Francisco-y hasta a la Virgen huyendo despavoridamente de la prédica del sacerdote.

El escrito nos aporta los siguientes elementos:

Cristo.

iAhora sí, ya empezó

A predicar don Hilario!

Puf! I ya se destapó!

Que otros le escuchen, no yo

Que tengo las orejas icanario!

La Virjen

iVámonos hijos de aquí!

I luego, inmediatamente,

Que no debe a esta serpiente

Oir, me parece a mí,

Una señora decente.
De su Madre o de nosotros.

Todo es hablar del Gobierno, I sus ministros de Estado...

iQué diferente, Señor

Era tu prédica Santa!

La de esta víbora espanta,

Pues con el odio i rencor,

La lengua se le atraganta.

Si este reptil de sotana

Viene a darnos mal ejemplo,

I lo más santo profana,

Para abandonar el templo

parte activa en las disensiones civiles". Miguel Luis Amunátegui, Diego Barros Arana, La Iglesia frente a la emancipación americana, introd. de Hernán Ramírez Necochea, $2^{a}$ ed., Santiago, Austral, 1960 (Col. Realidad Americana), p. 108.

${ }^{18}$ Sacerdote que el gobierno chileno había propuesto al Vaticano como candidato en reiteradas ocasiones para la vacancia del arzobispado de Santiago, siendo rechazado por sus tendencias liberales. El problema fue que con esta denominación: "Nació de aquí un conflicto que afectaba directamente las prerrogativas del gobierno para ejercer en su plenitud el Patronato Nacional. Extenso sería exponer la serie de negociaciones, de intrigas y proyectos de acuerdo, que hubo en torno de las reclamaciones continuas del gobierno y las obstinadas resistencias de la Cancillería Romana". Julio Bañados Espinoza, Balmaceda, su gobierno y la revolución de 1891, 2 vols., Santiago, Garnier Hermanos, 1894, vol. I, p. 47. 
Cristo: Pues han llegado al pináculo

Del ludibrio con su eterna

grosería, no hallo obstáculo

para irme del tabernáculo,

convertido ya en taberna.

Haga, Madre, sus maletas

I vámonos de este Infierno,

Que estos clérigos trompetas

Harán perder las chavetas,

Hasta al mismo Padre Eterno.
Al Cielo, al Cielo al instante!

Despierta, Pedro, despierta!

Despierta, viejo tunante!

I véte, Pedro adelante

Para que me abras la puerta.

Quédense aquí los indignos,

I, aunque a mi interés no cuadre,

Hagan mil i un desatinos.

Me voi, me voi con mi Madre

I todos mis inquilinos!

Al seguir con la línea que reprocha lo que un liberal considera la intromisión de la Iglesia en asuntos políticos - al mencionar en la prédica asuntos de gobierno-, se desprende la idea de que si los santos, Virgen y Jesús huyen por no soportar más el desvío del mensaje de fe que debiera entregarse en las iglesias, se debería a que la inclusión de asuntos ajenos a los espirituales era frecuente en los sermones. A juicio de Allende, esto llevó a que la difusión y recuerdo del mensaje cristiano haya quedado relegado a un segundo plano; junto con el que el sacerdote pase a ser demonizado, tratado de víbora al no preocuparse de los asuntos espirituales y del bienestar de las almas, puesto que su mayor labor parece ser la concientización de sus feligreses. Aquellos que oyen la mala prédica, podríamos decir, los conservadores, son considerados indignos, por no pensar por sí mismos.

Se observa nuevamente que para el autor la conexión entre Iglesia y conservadores es íntima e inseparable, donde la crítica principal es la utilización del púlpito como elemento de difusión políica, lo que habría ido en contra de la misión original de la misma: la prédica del mensaje de Cristo. 


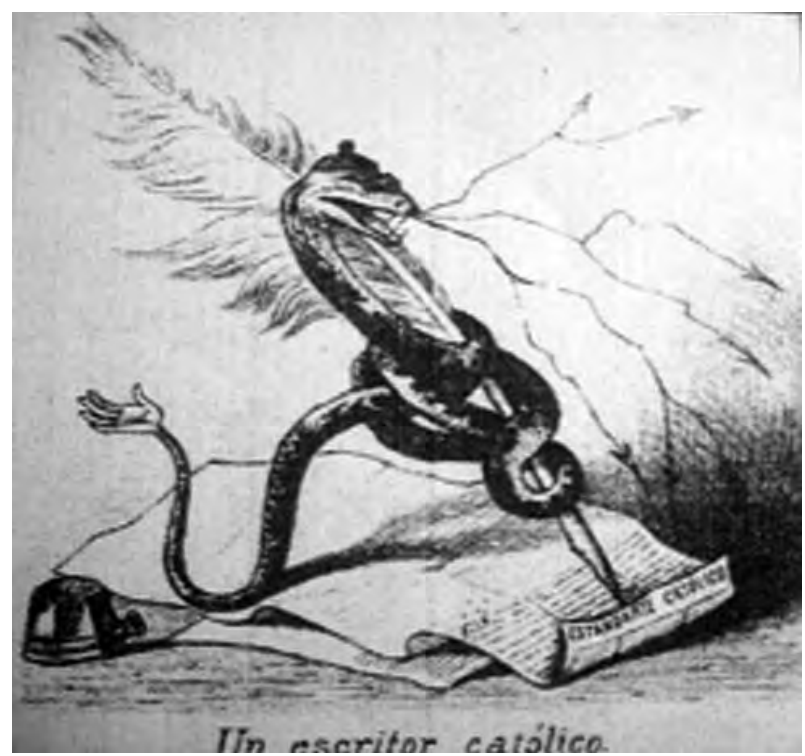

Imagen 4: Un escritor católico, en El Padre Padilla, núm. 258, sábado $1^{\circ}$ de abril, 1886.

La imagen 4 resulta llamativa por lo explícito de su crítica a los escritores del más insigne diario conservador de la época: El Estandarte Católico. ${ }^{19}$ Es conocido que la serpiente se considera símbolo importante en el mundo cristiano y en la cultura occidental, al vincularse tradicionalmente como un símbolo del mal y de oposición a Dios, ${ }^{20}$ por lo que podríamos interpretar que quienes escriben en dicho periódico no siguen el camino de Dios, sino que están contra él.

${ }^{19}$ El Estandarte Católico fue fundado en el año 1874. Reemplazó a la Revista Católica, al tratar de convertirse en la competencia del diario liberal más importante de la época: El Ferrocarril. De allí que en sus editoriales hayan sido frecuentes las críticas al gobierno, a las reformas teológicas, y a cualquier intento de separación entre la Iglesia y el Estado. Además, se usaba para difundir textos de eminentes figuras del catolicismo romano, así como actividades que realizaba la Iglesia a lo largo de Chile.

${ }^{20}$ Jorge Blaschke, Enciclopedia de los símbolos esotéricos, Barcelona, Robinbook, 2001, 256 pp. 
Una vez más nos encontramos con un símbolo ya utilizado: el de los rayos que despide la víbora desde su boca, a la vez que escribe en el papel que señala ser parte de El Estandarte Católico. Éstos, con puntas de flecha (como la cola de Satán) son indicados por algunos autores, por ejemplo Filippo Picinelli, ${ }^{21}$ como un símbolo del juicio final, pero también como un indicador de la envidia; lo que en este caso tendría que ver con el ataque que el diario efectuaba de modo constante contra el gobierno de turno (en esos años liberal), y contra cualquier intento de eliminar alguna de sus prerrogativas legales o de hecho.

El texto que acompañaba a la imagen, señala:

- ¿Qué víbora es esa padre?

Una figura simbólica,

defensor de Nuestra Madre

la Santa Iglesia Católica.

- iQué horrible i venenosa!

De aplastarla me dan ganas...

Pero... le falta una cosa...

Sí, le faltan las sotanas...

Podríamos agregar entonces que, a falta de la mencionada sotana, se encuentra el phiro o gorro sacerdotal tradicional. Se confirma entonces el ataque a la defensa que efectuarían los diferentes redactores y editores del diario El Estandarte Católico a la Iglesia católica, puesto que ellos, finalmente, no serían los representantes de Dios en la tierra, al igual que tampoco lo serían los sacerdotes.

${ }^{21}$ Filippo Picinelli, El mundo simbólico: los cuatro elementos, Eloy Gómez, Rosa Lucas y Bárbara Skinfill[eds.], trad. de Pascual Guzmán de Alba, México, El Colegio de Michoacán, 1999, pp. 167169. 
LA REACCIÓN DE LOS SECTORES CONSERVADORES Y DE LA IGLESIA ANTE LAS IMÁGENES Y ESCRITOS DE LA PRENSA SATÍRICA CHILENA

Ante los calificativos despectivos que emitía Juan Rafael Allende, los sectores aludidos no podrían quedarse en silencio. La reacción oficial de la Iglesia —difundida y apoyada por los conservadores- se manifestó a través de El Edicto sobre las malas lecturas, expedido por el obispo capitular de Santiago, Joaquín Larraín Gandarillas, en septiembre de 1886. En este documento se culpaba a las malas lecturas de debilitar la fe, ser el camino a la perdición, etc., puesto que:

[...] los libros irrelijiosos [sic] tienen por objeto oscurecer esas verdades -las de la Iglesia católica y el cristianismo en torno a la salvación del alma-, cuando no negarlas abiertamente, llevando la duda a las intelijencias con sofismas hábilmente encubiertos, con mofas que tornan en ridículas las más santas prácticas de la relijión, con calumnias inventadas contra la Iglesia o con hechos históricos falseados i [sic] citas mutiladas. ${ }^{22}$

Los libros, debido a su alto costo, no eran accesibles a todos, por lo que el mayor peligro se encontraba en la prensa escrita, ya que: "[...] es sabido que disponen de mayores i más eficaces recursos de perversión en la fé i en las costumbres [...]. El daño que causan los periódicos impíos e inmorales está en proporción con el número de sus lectores. No todos tienen recursos para comprar libros, al paso que hasta los más pobres pueden proporcionarse los malos periódicos", ${ }^{23}$ sumándose a su accesibilidad económica el hecho de que: "[...] en ellos se redoblan los peligros de las malas lecturas, ya por la variedad de formas, que hacen el ataque accesible a todas las inteligencias" . ${ }^{24}$ Pero los diarios El Padre Padilla y El Padre Cobos resultaban especialmente subversivos al incluir imágenes que podían ser entendidas por iletrados, lo que refuerza las posibili-

${ }^{22}$ Joaquín Larraín Gandarillas, "Edicto sobre las malas lecturas", en El Estandarte Católico, núm. 3737 , Santiago, 13 de octubre, 1886, p. 2.

${ }^{23}$ Rodolfo Vergara, "Un importante documento", en "Editorial" de El Estandarte Católico, núm. 3737, Santiago, 13 de octubre, 1886, p. 2.

${ }^{24}$ Larraín, op. cit., p. 2. 
dades de crítica social y de desafiliación religiosa. Esto queda plenamente comprobado cuando el Edicto explicitaba que:

Entre los malos periódicos ocasionan mayores daños a la moralidad social e individual aquellos que, a las doctrinas corruptoras, añaden el perverso aliciente de caricaturas, pinturas o estampas indecentes [...]. Mediante este recurso se consigue, por lo tanto, inocular de un modo más seguro i rápido la corrupción moral, sin que se esceptuen del contajio, las personas que no saben leer i las que, como los niños, no están en situacion de comprender las malicias de un artículo o el veneno de un folletín. ${ }^{25}$

Junto a esta contaminación moral producida por los diarios debido a sus muchas imágenes de alto contenido erótico, ${ }^{26}$ estaba el hecho de que se manchaba la honra de personajes públicos: "[...] haciendo aparecer contaminadas de vicios inmundos a personas dignas de respeto por sus méritos i virtudes, mediante los vedados recursos de la maledicencia i el ridículo". ${ }^{27}$ De allí que por medio de este Edicto se buscó impedir la lectura, circulación y difusión de estos diarios, condenando explícitamente a los periódicos de Allende y a los colaboradores del mismo, entendiéndose por tales a: "[...] los que los compran, leen, guardan o prestan; los padres i maestros que los introducen o permiten en sus casas o establecimientos de educación", ${ }^{28}$ bajo pena de pecado mortal.

Estas ideas se ven reforzadas en los editoriales de los días siguientes del periódico conservador El Chileno, el 14 de octubre de 1886 señalaba que entre los peligros que implicaba la prensa impía que: "[...] todos los días mancha con su contacto muchos hogares sanos i honrados" ${ }^{29} \mathrm{Al}$ día siguiente se agregaba que: "De hoi en adelante, los católicos ménos instruidos saben a qué atenerse sobre

${ }^{25}$ Loc. cit.

${ }^{26}$ Para un análisis respecto a este tema véase Maximiliano Salinas Campos, "Erotismo, humor y transgresión en la obra satírica de Juan Rafael Allende”, en Mapocho..., pp. 149-248.

${ }^{27}$ Larraín, op. cit., p. 2.

${ }^{28}$ Loc. cit.

29 "Editorial" de El Chileno, año III, núm. 886, Santiago, 14 de octubre, 1886, p. 3. 
la compra, suscripción i lectura de tan inmundos papeles" ${ }^{30}$ Resulta irónico el hecho de que en los párrafos siguientes se señale: "[...] la jente honrada, los verdaderos católicos, obedecerán gustosos los paternales consejos y las sabias prescripciones de su pastor", ${ }^{11}$ que es justamente lo que critican las caricaturas de los diarios censurados: la obediencia ciega al sacerdote por parte de sus feligreses.

No es casualidad que estas reacciones se hayan producido en 1886, año de elecciones presidenciales y en el que la sucesión arzobispal se vio zanjada; año del fin del gobierno de Domingo Santa María, quien con sus reformas: "[...] había dado vuelta al país, invirtiéndolo, confundiéndolo, como en un carnaval insoportable". ${ }^{32}$ De allí que, ante el avance de los gobiernos liberales, y ascensión al poder de José Manuel Balmaceda - quien era temido por el impulso dado a las reformas teológicas y por ser considerado un liberal acérrimo- el clero y los conservadores defendieran su honra y su influencia a toda costa, al atacar incluso a aquellos enemigos pequeños pero corrompedores, tales como la prensa satírica, que con sus grabados silenciosos podían engendrar graves peligros en las almas iletradas.

\section{CONCLUSIONES}

En cuanto a la investigación realizada respecto a la crítica de la mentalidad conservadora y religiosa por medio de la prensa satírica, creemos que nuestra hipótesis ha sido comprobada; lo que nos da cuenta de que entre las ideas centrales presentadas en los grabados y escritos de Juan Rafael Allende está: la posibilidad de traición a la patria por parte de los conservadores, en pro de la defensa de la Iglesia católica; la negativa influencia que ejerce el clero a través de sus prédicas, al olvidar el mensaje cristiano y potenciar el ataque político; la diferencia entre prédica y práctica, puesto que a juicio de Allende, los sacerdotes no cumplirían

\footnotetext{
${ }^{30}$ Ibid., 15 de octubre, p. 1.

${ }^{31}$ Loc. cit.

${ }^{32}$ Salinas, iYa no hablan de Jesucristo!..., p. 15.
} 
con los preceptos por ellos impulsados como el ayuno, la abstinencia, etc.; el ansia de poder que se escondería en la Iglesia, representado por Joaquín Larraín Gandarillas, quien es mostrado como un hombre capaz de hacer de todo para lograr sus objetivos, y que se ve seriamente afectado al no obtener ser confirmado como arzobispo de Santiago.

Respecto a la respuesta dada por la Iglesia y sectores conservadores, el hecho de que se haya expedido un edicto nos indica que el alcance de esta prensa debe haber sido amplio, y en realidad la Iglesia y los conservadores deben haber sentido que se estaban potenciando malas costumbres y prácticas para que valiese la pena redactar un documento con las características señaladas. En este sentido, y tal como lo expresa el mismo documento y los editoriales citados de El Chileno: el principal peligro residía en las imágenes, capaces de llegar a los ignorantes y a los niños, sujetos que por su escasa educación no serían capaces de distinguir entre el bien y el mal.

Adicionalmente creemos que hay una demonización de un sector y de otro: de los liberales hacia los conservadores al presentarlos como avaros, inconsecuentes y manipuladores; mientras que de los conservadores hacia los liberales la imagen se hace crítica desde la moral, el incumplimiento de las buenas costumbres, carente de valores cristianos de las que el primer sector se hacía estandarte. Queremos finalizar con una cita de Antonio Romera respecto al peligro que de modo tradicional se ha visto en el cómic como herramienta político-social: "Hay quienes censuran la caricatura de violenta, injusta, provocativa, turbulenta, apasionada, despiadada, cruel [...]. La caricatura, realmente violenta y anárquica sino en los días de efervescencia social, mas no se diga por eso que es arma sólo en las horas críticas de las revoluciones, su misión más adecuada no consiste en retratar revoluciones, sino en prepararlas". 33

Recibido: 30 de marzo, 2010.

Aceptado: 27 de mayo, 2010.

${ }^{33}$ Romera, op. cit., p. 319. 
BiBLIOGRAFÍA

Alted Vigil, Alicia y JuAN Belén SÁNCHez, Métodos y técnicas de investigación en historia moderna e bistoria contemporánea, Madrid, Universitaria Ramón Areces, 2005, 288 pp.

Amunátegui, Miguel Luis y Diego Barros Arana, La Iglesia frente a la emancipación americana, introd. de Hernán Ramírez Necochea, 2a ed., Santiago, Austral, 1960 (Col. Realidad Americana), 185 pp.

Aróstegui, Julio, La investigación histórica: teoría y método, Barcelona, Crítica, 1995, 460 pp.

Bañados Espinoza, Julio, Balmaceda, su gobierno y la revolución de 1891, 3 vols., Santiago, Garnier Hermanos, 1894, 720 pp.

Bernedo, PAtricio, "Prensa e Iglesia en el Chile del siglo xix: usando las armas del adversario", en Cuadernos de Información, núm. 19, Facultad de Comunicaciones, Universidad Católica de Chile, pp. 102-108. En http://fcom.altavoz. net/prontus_fcom/site/artic/20061206/pags/20061206101836.html

BlaschKe, Jorge, Enciclopedia de los símbolos esotéricos, Barcelona, Robinbook, 2001, 256 pp.

Cirlot, Juan Eduardo, Diccionario de símbolos, epílogo de Victoria Cirlot, $10^{\mathrm{a}}$ ed., Barcelona, Siruela, 2006, 497 pp.

Fuentes, Jordi y Lía CorTés, Diccionario político de Chile (1810-1966), Santiago de Chile, Orbe, 1967, 532 pp.

MejÍAs Alonso, Almudena y Alicia Arias Coeluo, "La prensa del siglo Xix como medio de difusión de la literatura hispanoamericana", en Revista General de Información y Documentación, vol. 8, núm. 2, Madrid, 1998, pp. 241-257.

Ossandón, Carlos, El crepúsculo de los sabios y la irrupción de los publicistas, Santiago, Lom, 1998, 127 pp.

Picineul, FuipPo, El mundo simbólico: los cuatro elementos, Eloy Gómez, Rosa Lucas y Bárbara Skinfill[eds.], trad. de Pacual Guzmán de Alba, México, El Colegio de Michoacán, 1999, 513 pp.

Romera, Antonio R., "La caricatura moderna", en Atenea. Revista Mensual de Ciencias, Letras y Artes, año XVIII, t. LXIV, núm. 192, Santiago, junio de 1941, pp. 306-319. 
LA MENTALIDAD CONSERVADORA Y LA IGLESIA CATÓLICA: CRÍTICAS Y DEFENSA A TRAVÉS DE LA PRENSA SATíRICA...

Salazar, Gabriel y Julio Pinto, Historia contemporánea de Chile: niñez y juventud, 5 vols., Santiago, Lom, 2002, 296. pp.

Salinas, Maximiliano, YYa no bablan de Jesucristo! Las sátiras al alto clero y las mentalidades religiosas en Chile a fines del siglo XIX, Santiago, Lom, 1999, $52 \mathrm{pp}$.

,"Erotismo, humor y transgresión en la obra satírica de Juan Rafael Allende", en Mapocho, Revista de Humanidades y Ciencias Sociales, núm. 57, Santiago, 2005/1, pp. 149-248.

SERRANo, Sol, Universidad y nación: Chile en el siglo xix, Santiago, Universitaria, 1994, 276 pp.

Tucci Carneiro, María LuzZa, "La Guerra Civil Española a través de las revistas ilustradas brasileñas: imágenes y simbolismos", en Estudios Interdisciplinarios de América y el Caribe, vol. 2, núm. 2, 1991/2. En: http://www.tau.ac. il/eial/II_2/carneiro.htm.

PERIÓDICOS

El Padre Cobos, Santiago, martes 30 de enero, 1883.

El Padre Padilla:

- Santiago, 4 de noviembre, 1884.

- Santiago, 28 de noviembre, 1884.

- Santiago, 10 de diciembre, 1885.

- Sábado $1^{\circ}$ de abril, 1886.

El Estandarte Católico, Santiago, 13 de octubre, 1886.

El Chileno:

- año III, núm. 886, Santiago, 14 de octubre, 1886.

- año III, núm. 887, Santiago, 15 de octubre, 1886.

latìno mérica 51

(MÉxico 2010/2): 63-83 83 